\title{
Dinamik ve Yüksek Frekanslı Fiyat Endeksi: Türkiye'nin Günlük ve Saatlik Bazda Enflasyon Hesaplamasi'
}

Serkan GENÇER ${ }^{2}$ - Veysel ULUSOY ${ }^{3}$

Makale Gönderim Tarihi: 23 Aralık 2020

Makale Kabul Tarihi: 20 Ocak 2021

\section{Öz}

Resmi istatistikleri tamamlayıcı nitelikte olması amacı ile online fiyatlardan günlük veya saatlik yani daha sık frekanslı fiyat endeksleri olușturulabilir. Bu çalıșma, günlük takip edilen faiz ve enflasyon oranı ile finansal piyasalardaki getirilerin yanına onları etkileyen ve reel getiriyi ölçmek için gerekli olan günlük ya da saatlik enflasyonu ölçmeyi amaçlar. Ayrıca, bu çalıșma ile Türkiye İstatistik Kurumu'nun (TÜiK) aylık bazda ölçtüğü resmi enflasyon rakamlarının yapılan bu sistem ve yöntem ile karșılaștırıcı, geliștirici ve kontrol edici fonksiyonlarını değerlendirme amaçlanmıștır.

Anahtar Kelimeler: Finansal Ekonomi, Alternatif Enflasyon Hesaplaması, Online Enflasyon, Dinamik ve Yüksek Frekanslı Fiyat Endeksi, Türkiye İstatistik Kurumu (TÜIK)

JEL Sıniflandırması: B41, C63, C82, C88, E31

1 Bu makale 15-17 Ekim 2020 tarihleri arasında Konya'da düzenlenen 4. Ekonomi Araștırmaları ve Finansal Piyasalar Kongresinde sözlü bildiri olarak sunulmuș ve kongre bildiri kitabında özeti yayınlanmıș bildirinin genișletilmiș halidir.

2 Yeditepe Üniversitesi, Finansal İktisat Doktor Adayı, Alan Yatırım, Hazine Müdürü, serkangen@hotmail.com, Orcid ID: 0000-0003-4310-6852

3 Prof. Dr., Yeditepe Üniversitesi, Sosyal Bilimler Enstitüsü, vulusoy@yeditepe.edu.tr, Orcid ID: 0000-0001-7227-894X 


\title{
Dynamic And High Frequency Price Index: Calculation Of Turkey's Daily And Hourly Inflation
}

\begin{abstract}
The Prices collected from online resources can be used to construct daily or hourly price indexes that complement offical statistics. This paper aims to measure daily or hourly inflation rate which is necessary to measure real return and affects them deeply together with returns obtained from financial markets and daily monitored interest and inflation rates. In addition, this study aimed to evaluate the ability of comparison, improving and control functions of our system and method against the offical inflation rates obtained by Turkish Statistical Institute (TSI) on a monthly basis
\end{abstract}

\section{JEL Classification: B41, C63, C82, C88, E31}

Keywords: Financial Economics, Alternative Inflation Calculation, Online Inflation, Dynamic and High Frequency Price Index, Turkey Statistics Institute (TSI)

\section{Giriș}

2000 yılının bașlarından itibaren internetin ve teknolojinin geldiği noktalara baktığımız zaman bilginin fazlalașması ve kolay ulașılabilir olması, çalıșmaları da bir o kadar hızlandırmıștır. Merak edilen herhangi bir konu internet ortamında bir cümle yazılarak bulunabilmekte veya istenilirse öğrenilebilmektedir. Bunun ile beraber alıșveriș alıșkanlıklarımızda da bu süre zarfında toplum olarak gözle görülür değișiklikler yașiyoruz.

Bu nedenle, insanlar yerinde gidip görmekten çok internet üzerinden online olarak inceleyip bu ürün ve hizmetleri herhangi bir efor sarf etmeden almak istemektedir. Özellikle Covid-19 salgınından sonra insanlar dıșarı çıkmak istememekte ve toplu bir șekilde bulunmaktan kaçınmaktadırlar. Ülkeler, online ders ve uzaktan çalıșma gibi yöntemlere muhafazakar yaklașsalar da bu yöntemleri uygulamak zorunda kaldılar ve online hayat daha önemli bir hal aldı. Toplantılar, görüșmeler, yapılan alıșverișler uzaktan online bir șekilde yapılmaya bașlandı. Global olarak yașanmakta olan pandemi önümüzdeki senelerde azalsa veya tamamen bitse bile bu tüketici davranıșlarının ve alıșkanlıklarının çok değișken olmasını beklemiyoruz. Buna bağlı olarak, online yașamın artık 
daha fazla önem kazandığına ve geleneksel çalıșmaların da buna ayak uydurması gerektiğine inanıyoruz.

Online fiyatlar, internetin global yapısından dolayı ülke bazında bize online fiyat endeksi olușturabilme imkanı sağlamaktadır. Bu olușturulan online fiyat endeksleri ile ÜFE, TÜFE, Konut endeksi gibi çeșitli endeksleri olușturabilmemiz mümkündür. Ancak, bu çalıșmamızın kapsamı ve konusu gereği bu online fiyatlar ile enflasyon hesaplamasını sadece Türkiye bazında yaptık. Türkiye'nin resmi istatistik kurumu olan TÜiK'in elde ettiği verilerin aksine topladığımız mikro datalar TÜiK'in topladığı veri miktarından kat ve kat fazladır. Bu mikro data toplama ișlemi kendi olușturduğumuz özel bir yazılım ile gerçekleștirilmektedir. Belirtildiği gibi bu çalıșmanın pek çok potansiyel kullanımı olup, gelișmekte olan ülkelerde yașanan ekonomik zorlukların kaynağını olușturan enflasyonun ekonomik hayatı her dakika etkilemesi ve fiyat artıșlarının alım gücünü günlük bazda etkileyerek hem hane halkı tüketimini hem de yatııım harcamalarını etkilemesi çalıșmamızın önemini artırmaktadır.

Bu çalıșma sonucunda elde edilen veriler, öncelikli olarak resmi tahminleri karșılaștırma, kontrol ve değerlendirme amacı ile kullanılacak olup, resmi verilerin benzer metodolojik yaklașımlarını ve özellikle ağırlıklarını kullanmamız açısından, küçük yaklașım değișiklikleri ile dinamik enflasyon ölçümünde nelerin hangi hızda yanıt verdiğini elde etmemiz açısından önemlidir. Özellikle pandemi döneminde tüketim ve tasarruf alıșkanlıklarının yeniden șekillenmesi ile TÜFE sepet yapısı da değișime uğramıș, yeniden dizayn edilen ağırlık ve sepet içeriği gibi olușumları hemen görme olasılığı ortaya çıkmaktadır. Ayrıca, gün bazında olabilecek herhangi bir zam, indirim ve benzeri durumlarda online endeksimizin bu fiyatları enflasyona nasıl yansıttığını da ayrıca inceleyeceğiz.

Data toplama çalıșmasının bașlangıç baz gününü 26 Ağustos 2020 olarak belirledik. O günden itibaren tüm data toplama ve saklama ve hesaplama çalıșmaları günlük bazda olușturduğumuz yazılım programı tarafından yürütülmektedir. Bu yazılım her gün kullanııının belirlediği matris girdisi ile ilgili kalem bazında ürünleri ve hizmetleri taramaktadır ve her ürün ve hizmet bazında fiyat bilgisini almaktadır. Bu çalıșmada 30'dan fazla kurumsal ve özel/kamusal yapıdan olușan online fiyat endeksi bu çalıșmada analiz edilecektir. Sözü edilen ve fiyatların alındığı yapılar/kurumlar, Türkiye içinde faaliyet göstermekte olup, bazıları sadece online veya fiziki, bazıları ise her iki șekilde hizmet verebilmektedir. 
Olușturduğumuz online fiyat endeksi, standart TÜIK'in kullandığı Tüketici Fiyat Endeksi (TÜFE) metodolojisini ve ağırlıklarını kullanmaktadır. Buna karșın, yazılımımız kalite ve standardizasyon takibi yapmamakta olup, bu takip yerine 1713 yılında İsviçreli matematikçi Jacob Bernoulli'nin Ars Conjectandi isimli kitabında kanıtladığı "Büyük Sayılar Yasasına" istinaden birbiri ile aynı kategoride olan olabildiğince fazla fiyat bilgisi alıp dağılımda olabildiğince normalleșme ile olması gereken teorik ortalamayı bularak son endekse gitme yöntemi tercih edilmiștir. Bu yöntemde önemli olan havuza girecek olan fiyatların kalem bazında birbiri ile alakalı veya aynı olabilmesidir. Yazılımımız, örneğin, "Dana Eti" kaleminde müșteriye sunulan tüm çeșit ağırlık ve türdeki ürünlerin fiyat verilerini almaktadır. Diğer taraftan üst kalem daha kapsayıcı bir isim barındırıyorsa örneğin "ağız ve diș bakım ürünleri", bu kalemde daha fazla ürün çeșitliliği bulunacağı için yazılım üst endekslemenin alıında bir alt endéksleme daha olușturmaktadır. Ürün çeșitliliğinden kaynaklanan fiyat farklılıkları ve endekslemede ortalama bazında küçük rakamların katkısı küçük olacaktır. Bunun için alt endeks hesaplamalarında geometrik ortalamayı kullanarak sayısal küçüklükteki fiyatlarda olası bir değișimde etkisinin sayısal büyüklükteki rakamlar ile aynı olması amaçlanmaktadır.

Figür 1: Endeks Olușturma Metodolojisi Örnek Diagram

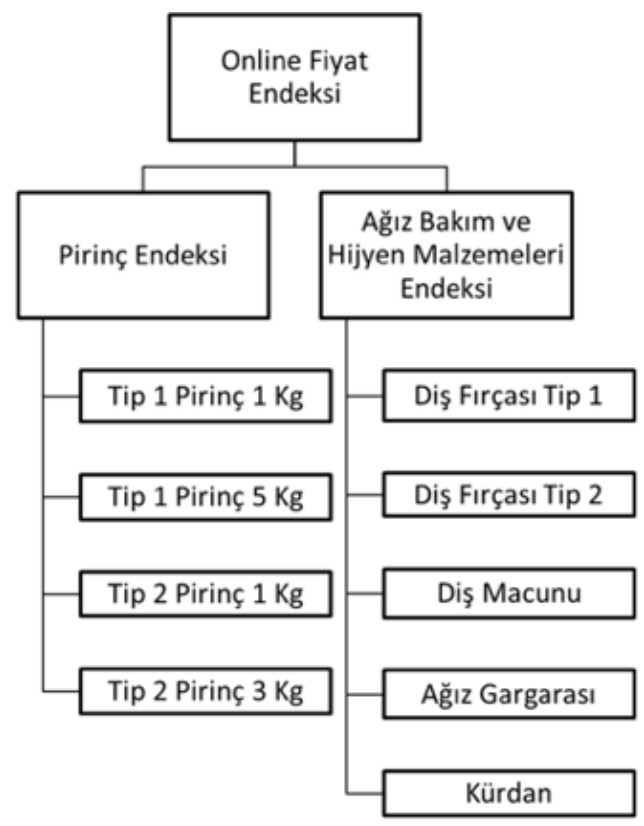


Fiyat verilerinin alındığı kaynakların özellikle popülasyonun tamamını ve gelir dağılımlarını olabildiğince temsil edebilmesini önemsemekteyiz. Buna bağlı olarak örneğin, Türkiye popülasyonunun yüzde kaçı bu fiziki ya da online satıș sisteminden faydalanabiliyor, mevcut market veya marketler zinciri her șehirde var $\mathrm{ml}$, var ise her ilçede var $\mathrm{mI}$, en azından büyük șehirlerde var ise satıș segmenti iskonto perakendecisi bazında mı yoksa orta gelir grubuna mı hitap ediyor? șeklindeki sorulara yanıt verebilmektedir. Genelde tek kalem bazında bakıldığında sadece bir kaynaktan değil çoklu kaynaktan mikro datayı almaya ve her tüketici kesimini ve popülasyonu olabildiğince temsil etmesini sağlamaya çalıșıyoruz. Hazırlamıș olduğumuz yazılım programı bu kıstaslar üzerinden bu mikro data alımlarına öncelik sağlamaktadır.

\section{Literatür Taraması}

Buna benzer bir çalıșma yaklașık 12 yıl önce iki kiși tarafından bașlatılmıș olup, ilgili çalıșma enflasyonist sorunlar yașayan Arjantin ile bașlamıștır. Söz konusu kișiler șu anda Harvard Business School'da profesör olan Alberto Cavallo ve MIT profesörü Roberto Rigobon, bu çalıșmaların ilk örneklerini akademik araștırma olarak ortaya koymuștur ve bu çalıșma metodolojisi ile ilgili bugüne kadar yeni bir çalıșma ortaya atılmamıștır. Bunun yerine genelde finansal enstrümanlardan olușan endeksler yaratılmaya çalıșılmıș ve günlük ölçümler buna göre yapılmaya çalıșılmıștır ki bu gerçek bir enflasyon göstergesi olarak kabul edilemez.

Yapılan bu çalıșma ile mevcut geçmișteki akademik çalıșmalar karșılaștırıldığında, izlenen yöntem benzerlikler göstermektedir ve bu çalıșmamızda da Alberto Cavallo çalıșmasında olduğu gibi "web scraping" yöntemi kullanmaktayı.

Ayrıca Cavallo'nun ülke bazında yaptığı pek çok sağlamlık testleri, herhangi bir mikro data elde etme veya metodolojik değișikliğin, hesaplanan online enflasyon verisi ile resmi açıklanan enflasyon tahminleri arasında çok ciddi farklar yaratmaması gerektiğini göstermektedir (Cavello 2013).

\section{Model Hakkında}

Olușturduğumuz online fiyat endeksimizdeki yazılım programı, online fiyat bilgisi ile resmi kategori ağırlıklarını kullanmakta olup, kalite ve standardizasyon takibi yerine olması gereken teorik ortalamayı "Büyük Sayılar Kuramına" göre olabildiğince çok örneklem alarak dalgalanmayı minimuma indirmeye çalıșmakta ve kalem bazında olabilecek 
teorik bir ortalama fiyat ortaya çıkarmaktadır. Genelde, Dünya'da faaliyet gösteren resmi istatistik kurumları, global ve genel kabul görmüș metodolojiyi kullanırlar. Nitekim, resmi istatistik kurumumuz TÜiK de aynı metodolojiyi kullanmaktadır. Bu bağlamda yazılımımızda yukarıdaki belirttiğimiz değișiklik dıșında aynı süreç izlenmektedir.

Öncelikli olarak günlük fiyat endeksini elde etmek için tüm TÜiK kapsamındaki kalemlerden bir matris olușturulur. $\bigcirc$ matris kapsamında alınabilen kaynaklar incelenir ve yazılım programına ilgili kaynak okutularak ilgili mikro data elde etme ișlemi gerçekleșir. Bu ișlem sonrasında alınan kaynak bazında data saklaması sağlanır.

İkinci ișleme geçmeden önce kaydedilen kaynaklarda bir hata olup olmadığını yazılım programı kontrol eder. Cavallo'nun bahsettiği hata kaynaklı "endeks boșlukları"nın olușmaması için hata varsa yazılım programı bir listesini çıkarır. Bu hata, iç yazılım kaynaklı ise düzeltmesini yapıp tekrar devam eder, ancak, dıșarı kaynaklı bir sorun yașar ise bunun bildirimini yapar.

İkinci așama olarak, bir sorun yok ise endeks kalemlerinin hesaplamasına geçilir ve kaydedilen bu mikro veriler kullanılır. Her kalem ve kaynak bazında verilen matrise alt endeks hesaplamasını geometrik ortalama ile $j$ kategorisinde ve $t$ günde $p$ fiyatını alarak yapan sistem:

$$
R_{t, t-1}^{i}=\prod_{i}\left(\frac{p_{t}^{i}}{p_{t-1}^{i}}\right)^{1 / n_{j, t}}
$$

Her endeksin alt kalemindeki alınan kurumların kendi içinde geometrik ortalamasını olușturduktan sonra o kalem alında ne kadar kurum var ise mevcut endeks değerlerinin aritmetik ortalaması alınır.

$$
I_{J}=\left(R_{J 1}+R_{J 2} \ldots R_{J n}\right) / n
$$

Formülizasyonuna göre $R$ endeksleri hesapladıktan sonra üst kalem bazında hesap yapmak için aritmetik ortalamayı kullanarak I üst endeksini elde etmekteyiz. Aritmetik ortalama ile avantaj ve dezavantajlarına bakılmaksızın farklı gelir grupları ve farklı popülasyon kesimlerini olabildiğince Türkiye çatısı alıında alabilmek amaçlanmaktadır. Örneğin Dana eti kaleminin alındığı 5 market var ise bunların bazıları indirim perakendecisi olup, toplumun belli bir gelir grubundaki nüfusu müșteri hedefi olarak seçiyor olabilir. Kimi market kendini orta gelir için konumlandırıp buna göre fiyatlama politikası izliyor olabilir. Bașka bir örnek olarak, bir marketin sadece büyük șehir merkezlerinde mağazaları olduğunu, ancak, 120 çeșit et ürünü sattığını varsayalım. Diğer bir tarafta ise 
her șehir ve her ilçede faaliyet gösteren, ancak kalem bazında 30 çeșit et ürünü satan bir market olduğunu düșünelim. Bu açıdan bakıldığında, 30 et ürününün popülasyonun daha fazlasına ulașma imkanı olmasına karșın, kalite ve standardizasyon takibi yapılamadığı için ise sayıların çokluğu gerektiği için aynı miktarda 120 çeșit et ürünü satan marketin de aynı önemi vardır. İkisinin eșit önemi olduğu varsayımı ile dana eti kategorisinde kaç market var ise hepsinin aritmetik ortalaması bu sebep ile yazılımda yer alır.

Son olarak, her kalem bazında son endeks rakamları olușturulduktan sonra ağırlıklı ortalaması alınarak endeks olușturulur. Bu noktada 2 yöntem kullanmaktayız. İlk yöntem yatay hesaplama ile kalem bazında bileșik getiri hesaplamasından sonra son endeks hesaplaması yapılır:

$$
r_{t}^{j}=R_{1,0}^{j} \cdot R_{2,1}^{j} \ldots R_{t, t-1}^{j}
$$

İkinci yöntem ise, dikey hesaplama ile önce her kalemin günlük bazda ağırlıklı ortalaması alınarak günlük bazda son endeksin takibi yapilır:

$$
S_{t}=\sum_{j} \frac{w^{j}}{W} I_{t}^{j}
$$

Buna göre, yazılım günlük online fiyat endeksini elde eder. Ayrıca, olabilecek hatalardan kaynaklı boșluklar için uluslararası standartlarda Bureau of Labor Statistics'in de kullandığı "cell-relative adjustments" yöntemi kullanılabilmektedir. Șu ana kadar yazılım programımızda herhangi bir hata kaynaklı gap yașanmamıș olup, ihtiyatlı olma açısından ilgili yöntem gerektiğinde kullanılabilecektir.

Günlük olarak hesaplanan günlük fiyat endeksinden aylık, hatta yıllık enflasyon tahminleri de elde edilebilir. Ancak, aylık hesaplamanın ve karșılaștırmanın yapılabilmesi için 2 aylık bir süre, yıllık bazda bu verileri değerlendirmek adına ise, cari yılın önceki yıl ile karșılaștırması için 2 yıl geçmelidir. Ancak, biz bu çalıșma ile günlük bazda takip yapmaktayız ve baz gün olușturarak bir ayda endeks ne kadar artıș göstermiș sorusunu cevaplayarak tahmini online enflasyon verisine ulașmaktayız. Burada önem vererek takip ettiğimiz en önemli etken fiyat endeksinin olușmasıdır. Bu endeks kapsamında çeșitli yan endeks ölçümleri ve benzeri çalıșmaların yapılması mümkündür. Ayrıca belirtmeliyiz ki mevcut sistemimiz ve belirttiğimiz çalıșma sadece günlük ve aylık enflasyon hesaplaması yapıyor șeklinde olsa bile, sistemimiz tarafından ayrıca değișik frekanslarda (haftalık, saatlik) enflasyon hesabı yapılabilmektedir. 
Figür 2: Yazılım Sistem Algoritma Diagramı

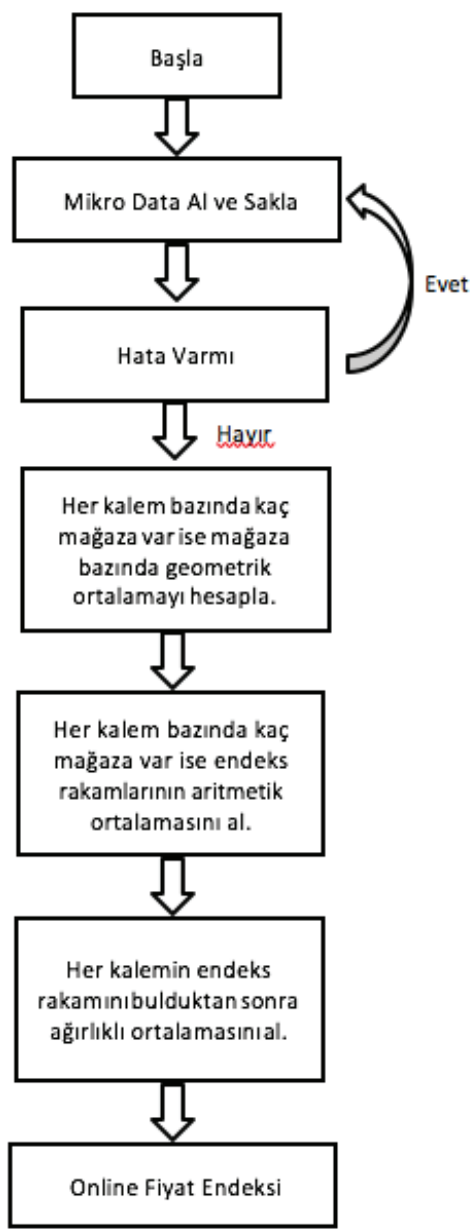

\section{Ampirik Sonuçlar}

\subsection{TÜIK ile Karșılaștırma}

Alberto Cavallo'nun çalıșmasında belirtilen fiyatların alındığı yapılar, ülke bazında yaklașık resmi TÜFE'nin en fazla \%55 ağırlığını alabildiklerini göstermekte olup, bu veri de fiyat alınan marketin piyasa paylarından kaynaklıdır. Ancak, Cavallo çalıșmalarında bu oranın da resmi enflasyon tahminlerinin kontrolü için yeterli olacağını belirtmektedir (Cavallo 2013). Biz çalıșmamızda bu ağırlıklarda teorik olarak TÜiK' in \%95'lik enflasyon sepetine kadar çıkabilmekteyiz. Șu an itibari 
ile standart yazılım resmi TÜiK ağırlıklarının \%79,8'ini alabilmektedir. Toplamda TÜiK'in açıkladığı 274 kalemin ağırlığı \%79,8'dir. Yazılımımız șu anlık bu 274 adet kalemi optimum performansı sağlamak için almaktadır ve enflasyon verisinin hesaplanması için kullanmaktadır.

Çeșitlilik açısından ise her kalemde ortalama yaklașık en az 3-4 çeșit ürün bulunmasına dikkat etmekteyiz. Örneğin, peynir çeșitlerinin içinde yaklașık tek bir üst kalem olarak 15 çeșit peynir bulunmakta ve fiyat bilgileri alınmaktadır. Mağaza sayısı açısından ise alınan kaynakların mağaza sayısı dikkate alındığında ve karșılaștırıldığında resmi rakamları geçmektedir.

Bu șekilde pek çok kaynaktan aldığımız bilgi açısından bu kriteri de sistemiz karșılayabilmektedir. Fiyat alma prosesi yaklașık 45 dakikada tamamlanmaktadır. Yani, her saat bașı bu sistem çalıștırıldığında saatlik enflasyon frekansını da elde etmiș oluyoruz. Ancak, mevcut sepetin içerdiği ürün ve hizmetlerin neredeyse hepsi saatlik enflasyonda fiyat değișimi sağlayan ürünler ve hizmetler olmadığından, günlük bazda devam edilmesini daha uygun bulmaktayız.

TÜIK' in açıkladığı resmi verilerinde, aylık enflasyonun tahmini için yaklașık 553.000 adet ürün fiyatı ve 4274 adet kira fiyatı aldıklarını belirtmișlerdir. Biz bu çalıșmamızda, bundan farklı olarak hem günlük hem de saatlik enflasyon hesabı yapabilen bir sistem ile günlük bazda yaklașık 245.000 adet ürün ve hizmet fiyatı ile 3.500 adet kira fiyatı toplayabilmekteyiz. Bu da aylık bazda yaklașık 7.472.500 adet ürün ve hizmet fiyatı ile 106.750 adet kira fiyatı toplamak anlamına geliyor. 26 Ağustos baz günü olarak bașlamıș olan yazılım yıllık bazda enflasyon hesabını yapabilir hale geldiğinde yaklașık 89.425.000 adet ürün ve hizmet fiyatı ile 1.277.500 adet kira fiyatı toplamıș olacaktır ki, bu rakamların üstüne çıkmak da mümkündür.

Tablo 1: TÜiK TÜFE Sayısal Bilgiler (Aylık bazda)

\begin{tabular}{|c|c|c|c|c|c|c|c|}
\hline \multirow[b]{2}{*}{ TÜFE } & \multicolumn{6}{|c|}{ Yillar } & \multirow[b]{2}{*}{ Sistemimiz } \\
\hline & 2015 & 2016 & 2017 & 2018 & 2019 & 2020 & \\
\hline Madde sayısı & 426 & 417 & 414 & 407 & 418 & 418 & 278 \\
\hline Çeșit sayısı & 945 & 924 & 910 & 895 & 895 & 897 & $>897$ \\
\hline İșyeri sayısı & 27198 & 27886 & 27386 & 28015 & 28711 & 28019 & $>28019$ \\
\hline Fiyat sayısı & 390984 & 408093 & 400772 & 415000 & 544256 & 553064 & $\sim 7472500$ \\
\hline Kira sayısı & 4290 & 4281 & 4275 & 4274 & 4274 & 4274 & $\sim 106750$ \\
\hline Ağırlık & $100 \%$ & $100 \%$ & $100 \%$ & $100 \%$ & $100 \%$ & $100 \%$ & $79,80 \%$ \\
\hline
\end{tabular}




\subsection{Varsayımlar}

Yaptığımız bu çalıșmada bazı varsayımlar ortaya konulmuștur. Olușturduğumuz sistem bölgesel fiyat değișimlerini dikkate alamadığından dolayı, bir șirketin kar maksimizasyonu mantığında her sattığı bölgede fiyatlar farklı olsa bile satması gereken kar marjının bir ortalaması olması gerektiği ve șirketin fiyatlama politikasını buna göre yaptığı varsayılmıștır. Yani, șirket kendine finansal tablolar bazında \%5 net kar mariı hedefi koymuș ise, lojistik giderlere bağlı olarak daha ucuza sattığı bölge olabileceği gibi daha pahalıya satabileceği bölgelerde olacaktır, ancak finansal planlama ve bütçeleme bazında \%5 kar mariı hedefine ulașmak isteyecektir. Buna göre, șirketin finansal tahmin veya kar tahmini planlamaları çerçevesinde bu kar mariına göre bir ortalama fiyatlama politikası uygulayacağını varsaymakłayız.

Bir diğer varsayımımız, fiyatlarda olabilecek volatilitenin sebepleridir. Buna göre, ilgili kalemdeki ürünleri satan kurumsal yapı, ilgili ayın belli dönemlerinde așırı indirim veya kampanyalar yapabilir. Sonraki günlerde tekrar önceki günlerdeki fiyatlarına dönüș görülebilir. Bu durum fiyatlarda volatilite yaratsa bile günlük bazda enflasyon hesaplaması yaptığımız için mevcut günde ürün çeșitleri o fiyattan tüketiciye sunulabilmektedir ve tüketici belirtilen indirimli fiyatlardan alabilmektedir. Yani, günlük bazda görülebilen düșüșler rasyonel bir mantığı barındirmaktadır.

Bir önceki varsayımımıza istinaden bazı ürünlerdeki volatilite envanter değișikliğinden kaynaklanabilir. Bu envanter değișikliği olsa bile, endeks kalemlerinin alıında sistem ayrı bir ara endeks hesaplamasına gittiği için ve tüketicinin bu ürün çeșitliliğine sadece o gün ulașabileceğini varsayarak o gün endeks havuzunda bulunan tüketim ürünlerinin bir üst endeksi temsil ettiğini varsayabiliriz.

Eğer kalem bazında endekse daha farklı bir șirket eklenir yada çוkarılır ise fiyat serisi geriye dönük bir șekilde kendini çıkacak ortalamaya göre düzeltebilir. Böylelikle sistem fiyat bütünlüğünü korumuș olur.

Bazı alınan datalar devlet kontrollü olup bunlara kesikli fiyatlar diyebiliriz. Yani, bu fiyatların güncellemesi günlük bazda olmayıp aylık bazda ya da çeyrek dönem bazında yapılmaktadır. Örneğin, akaryakıt fiyatları yurtdıșındaki spot fiyatlardan etkilendiği gibi, döviz kurundaki herhangi bir yükselme ya da azalma resmi kurumların dağııı fiyatlarında düzensiz güncelleme yapmasına sebep olmaktadır. Ancak, biz her 
halükarda bunların fiyatlarını da günlük almaktayız. Ancak, elektrik, doğalgaz gibi ürünlerin fiyatları sezonluk etkilenmekte ve gerek görüldüğü șekilde yine resmi düzenleyici kurumların dönemsel fiyat güncellemeleri olarak tüketiciye yansımaktadır. Bu durumda da yine fiyatlar yatay seyretse bile günlük takip etmekteyiz.

Șirket birleșmeleri veya dağılmaları gibi durumlarda ise örneklem sayısında azalma ya da artıș gözlemlenebilir. Bu gibi durumlarda sistem yeniden kendini geçmișe yönelik güncelleyerek data bütünlüğünün bozulmasını önleyebilir.

Enflasyonun daha da artması durumunda diğer Arjantin yada Venezüella gibi ülkelerde olduğu gibi ürünlerde devlet kontrolü gelebilir ancak bu durumda karaborsa gibi piyasalar olușabilir ve endekste volatilite yaratabilir. Bu kontrol kalktığı zaman șirketler fiyatlamayı daha agresif bir șekilde yapabilir. Bu da fiyatların yeniden așırı yükselmesine ve endekste volatiliteye sebep olabilir.

\section{3. Çalıșmanın Illk Sonuçları}

26.08.2020 gününü baz gün alarak bașlayan endeks 13.10.2020 tarihine kadar incelenmiș ve ilgili sonuçlar așağıda detaylandırılmıștır. Öncelikli olarak bahsettiğimiz iki endeks hesaplama yöntemi sonucunda iki farklı endeks olușmuștur. Birinin artıș hızı daha az iken diğerinin artıș hızı hem ilk yöntemden hem de resmi rakamlardan daha fazla olmuștur.

Grafik 1: Online Fiyat Endeksi (Online Enflasyon) Metodoloji 1

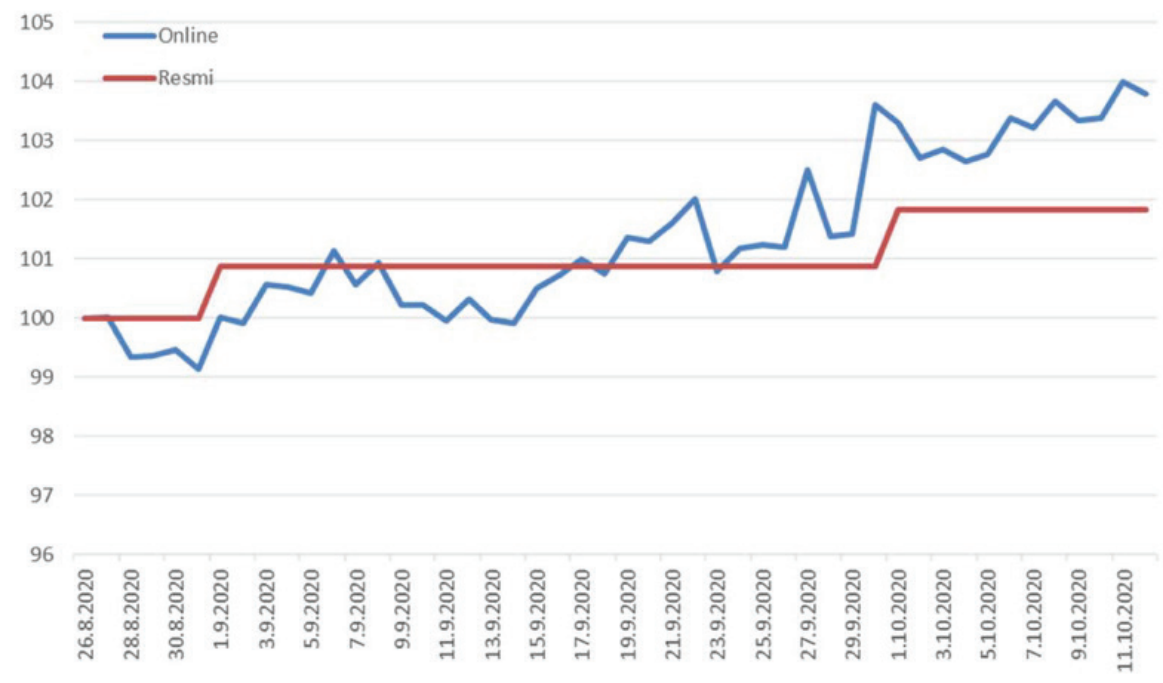


Grafik 2: Online Fiyat Endeksi (Online Enflasyon) Metodoloji 2

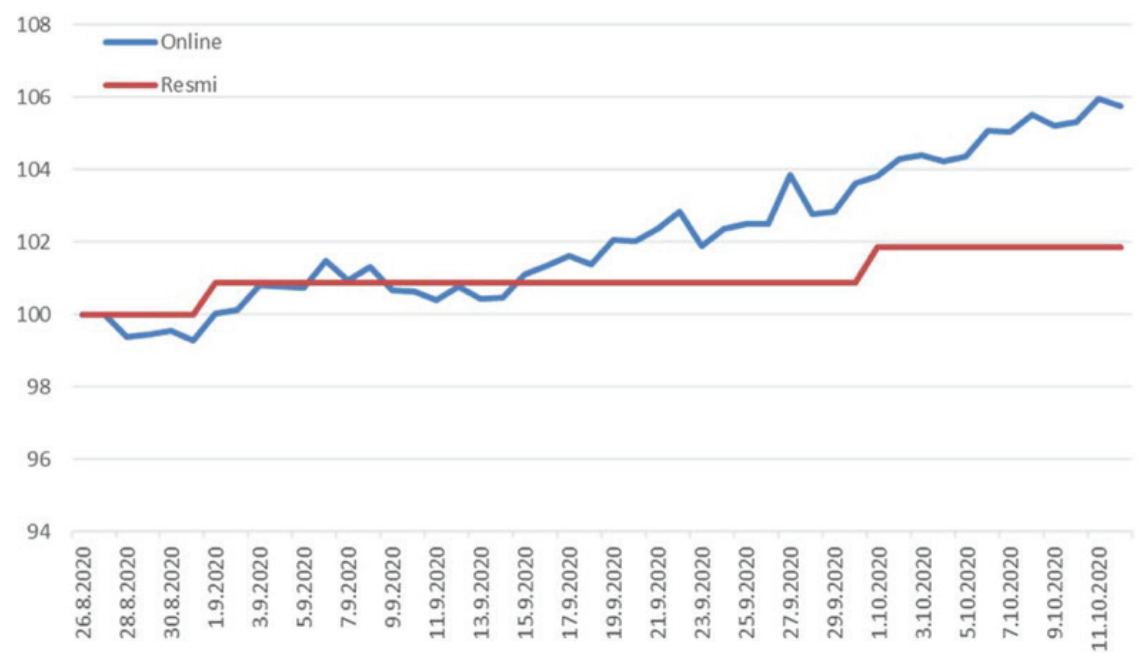

Grafiklerde görüldüğü gibi 2 yöntemde de farklı ancak açıklanan resmi rakamların üstünde bir enflasyon oranı hesaplanmıștır. Endeksimiz 26.08.2020 tarihinde bașladığı için baz günü 100 ile bașlatmıș ve metodoloji 1 e göre 13.10.2020 tarihli endeks rakamı 103,78'e, metodoloji 2 ye göre ise 105,77 ye ulașmıștır. Buna göre sonucumuz bașlangıç gününden beri enflasyon metodoloji 1 göre \%3,78, metodoloji 2 ye göre ise \%5,77 artmıștır. TÜiK'in açıkladığı resmi rakamlarla karșılaștırmak için baz günümüzden itibaren resmi veriler de 100 ile bașlatılmıștır. 2020 yılının Ağustos ayı enflasyonunun resmi rakamlara göre \%0,86, Eylül ayı için ise bir önceki aya göre \%0,97 arttığı TÜiK tarafından açıklanan enflasyon oranlarıdır. Ay bazlı açıklandığı için ay içindeki günlerin sabit olduğunu varsaymaktayız. Buna göre 13.10.2020 tarihli resmi endeks verimiz 101,84 olmuștur yani resmi rakamlara göre Türkiye enflasyonu baz gününden itibaren \% 1,84 oranında artmıștır.

Bu makasın gün geçtikçe daha açılacağı endeksteki pozitif eğim ile görülmektedir. Mevcut online fiyat endekslerindeki iki metodolojinin de artıș hızı resmi rakamlardan fazla. hesaplanmıștır. Buna göre zaman serisinde ilerleme yașandıkça iki serinin de korelasyon açısından ayrıșabileceği düșünülmektedir. Cavallo'nun önceki çalıșmalarda bulduğu sonuçlarla çalıșmamız benzerlik içermektedir. Arjantin ve Venezüella üzerinden çalıșma yapılmıș ve Arjantin'in karșılaștırılması için diğer Güney Amerika ülkelerinde ölçüm yapılmıștır. Metodoloji olarak bizim 
çalıșmamızla benzer yöntemi uygulayan Cavallo enflasyonist sorunlar yașamayan ülkelerde benzer veya yakın enflasyon oranları bulmuș, ancak, Arjantin'in enflasyon oranını açıklanan resmi rakamların 2-3 katı üstünde hesaplașmıștır. Șu ana kadar elde ettiğimiz sonuçlara göre Aylık bazda olmasa bile günlük bazda bu makasın Türkiye açısından da açıldığını görmekteyiz. TCMB beklenti anketine göre (TCMB, 2020) beklenen 2020 enflasyonu \% 1 1,46 olmasına rağmen bizim yılsonu beklentimiz yaklașık \%31 seviyelerindedir. Bu da yaklașık açıklanan resmi enflasyon beklentilerinin neredeyse 3 katı olmaktadır.

Tablo 2: Online vs Resmi Seriler

Online vs Resmi İstatistikler (26.08.2020 - 12.10.2020)

Türkiye

\begin{tabular}{lc}
\hline Ortalama Günlük Enflasyon (\%) & $1,250 \%$ \\
Online Endeks Metodoloji 1 & $2,130 \%$ \\
Online Endeks Metodoloji 2 & $0,997 \%$ \\
Resmi Endeks & 0,887 \\
Online ve Resmi Data Arasındaki Korelasyon Online Endeks Metodoloji 1 & 0,890 \\
Online Endeks Metodoloji 2 & \\
Online ve Resmi Data Arasındaki Regresyon Metdoloji 1 & 0,378 \\
Sabit & 0,000 \\
Sabit p-değeri & 0,786 \\
R2 değeri & \\
Metodoloji 2 & 0,260 \\
Sabit & 0,000 \\
Sabit p-değeri & 0,791 \\
R2 değeri &
\end{tabular}

\subsection{Zam Haberlerine Online Fiyat Endeksinin Tepkisi}

2020 Eylül ayı içinde pek çok kalemde zam haberleri yayımlandı. Bunlardan en önemlisi ise Eylül ayı bașında otomative yapılan \%8'lik ÖTV zammı oldu. Türk Hükümeti, alınan araçlardan belirli isimler altında vergi almakta ve bunlardan biriside Özel Tüketim Vergisi yani "ÖTV"dir. Bu haber ile endeksimizde gözle görülür bir sıçrama gözlemlemekteyiz. 1 1.09.2020 ve 18.09.2020 tarihlerindeki iki akaryakıt zammı yine ufak sıçramalara neden olmuș asıl yükseliș ise 02.10.2020 tarihinde yapılan \%5 e yakın elektrik zammı ile gözlemlenmiștir. 
Grafik 3: Online Fiyat Endeksinde Görülen Haber Etkisi Metodoloji 1

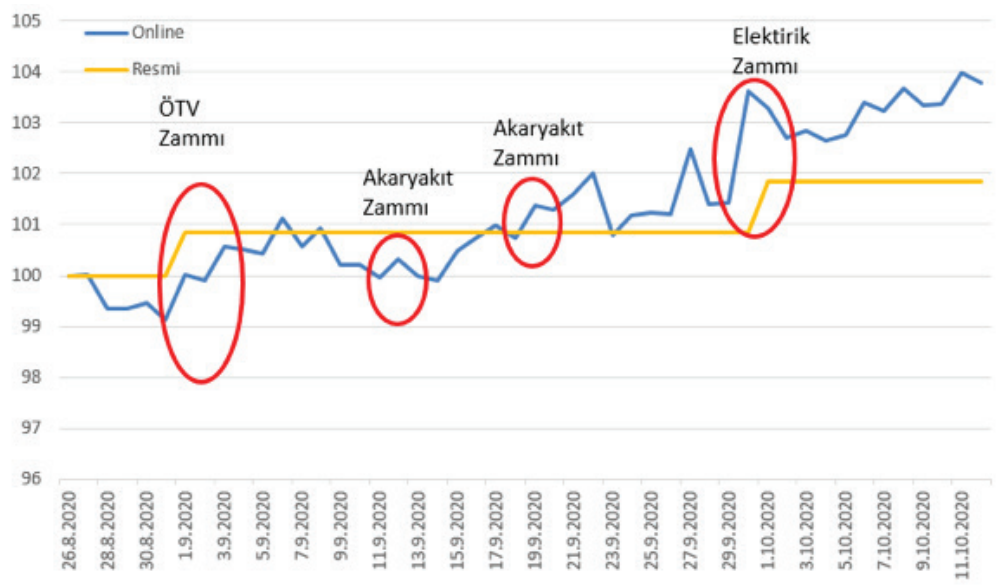

Grafik 4: Online Fiyat Endeksinde Görülen Haber Ełkisi Metodoloji 2

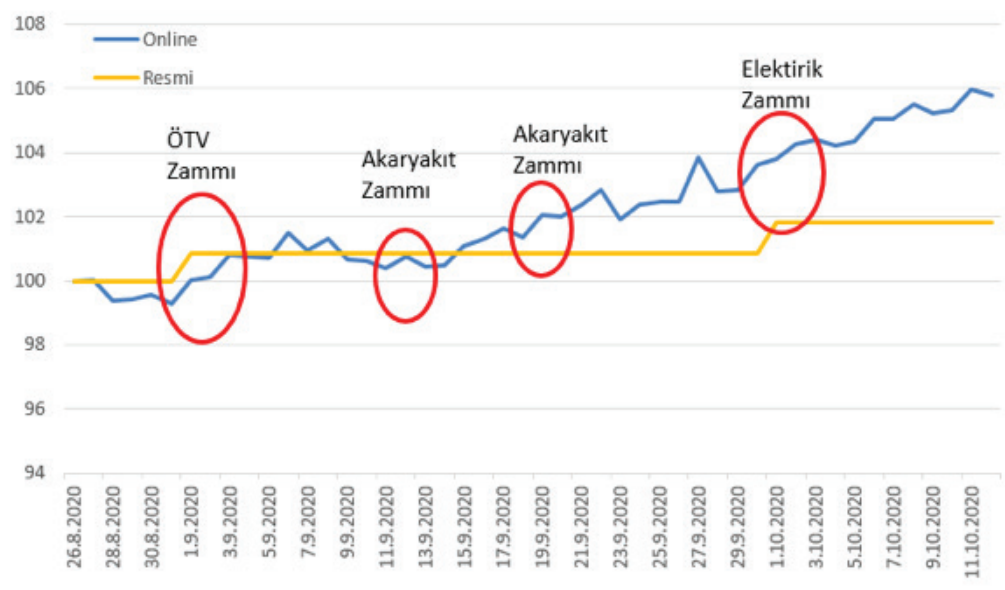

\section{Alternatif Uygulanabilecek Çalıșmalar}

Mevcut alt kalem bazında hesaplanan online endeksler aynı makroekonomik datalar için de kullanılabilir. Örneğin, emlak endeksi olușturulup ayrıca konut piyasaları takip edilebilir. Piyasada olabilecek anomalilerin tespitinde de bu endeksler kullanılabilir. Örneğin COVID-19 pandemisi kaynaklı alternatif enflasyon sepetleri olușturulabilir ve enflasyon bu bağlamda hesaplanabilir. Türkiye'ye COVID-19'un giriși 2020 Mart ayında olmuștur. Akabinde 3 ay hanehalkı evlerine kapanıp mümkün olduğunca dıșarı çıkmamıștır. Bu dönemin enflasyonunu ince- 
lediğimizde TÜiK tüm enflasyon sepetini hesaplasa da toplu tașımanın veya șehirler arası ya da ülkeler arası uçușların olmaması bu kalemlerin ağırlığını neredeyse 0 a indirmektedir. Buna göre, pandemi sepeti olușturulup bir enflasyon hesaplanması yapılması daha doğru olacaktır. Ancak, sistemimiz geriye dönük olası alternatif enflasyon sepetlerini de hesaplayabilmektedir. Burada önemli ola TÜiK'in hanehalkı tüketim anketini baz alarak tüketimlerin ne kadar hangi kalemde artıp azaldığının tespitidir. 3 aylık dönemde ülke içinde kolonya veya makarna stoklarının geçici olarak arz kaynaklı stoklarının tükenmesi buradaki tüketici davranıș anomalisine önemli bir örnektir. 3 aylık dönemden sonra kademeli olarak hane halkı yeniden günlük yașamına büyük ölçüde dönse bile üretim tarafında aynı geçiș kolay olmamıșıı. Otomativ üretiminin geçen yıla göre düșüș göstermesi ikinci el araç pazarındaki araçların anormal fiyat artıșlarına sebep olmuștur. Online endeksimiz bu anomaliyi de saptayabilmektedir. TÜiK otomotiv fiyatlarında sadece birinci el araçların fiyatlarını baz almaktadır. Bizde karșılaștırma açısından bu metodolojiye sadık kaldık. Ancak alternatif uygulama olarak ikinci el araç piyasasını da endekse ekleyerek bu anomaliyi saptayabiliriz ki sistemimiz bunu hesaplama için de entegre edilmiștir. Sadece TÜFE olarak değil ÜFE fiyatlarını da sistemimize entegre ederek online ÜFE endeksini olușturabiliriz. Bu alternatif metodlar temelde online fiyat bilgisini aldığı için aynı metodolojilerin diğer makroekonomik datalara uygulanması da uygundur ve sistem buna göre olușturulmuștur.

\subsection{Alternatif Metod Olarak GARCH Yönteminin Uygulanması}

Otoregressif koșullu değișken varyans (GARCH), 1982 yılında Robert $F$. Engle tarafından geliștirilmiștir. Model bir varyans modeli olup, finansal piyasalardaki volatiliteyi hesaplamak için kullanılmaktadır. Finansal piyasalarda olduğu gibi günlük enflasyon alt kalem endekslerimizde de volatilite görülmektedir. Mevcut modeli olușan alt endeks kalemlerindeki volatilitenin tahminlerde yaratacağı olumsuz etkiyi minimize etmekte kullanabiliriz. Bu model, sadece hesaplanan değil ileriye dönük alt endeks ve online fiyat endeksinin tahmininde yararlı olacaktır. Bunun dıșında kalem bazında endeksler yerine "Gıda endeksi" gibi toplu endeksler olușturulup birbirleri arasındaki geçișkenliğinde ölçülmesi yine GARCH yöntimi ile mümkündür. Bu sayede olası zamların geçișkenliğinin ölçülerek ileri yönelik tahminler yapabilmek mümkün olacakıı. 


\section{Sonuç}

Günlük takip edilen faiz ve enflasyon oranı ile finansal piyasalardaki getirilerin yanına onları en derinden etkileyen ve reel getiriyi ölçmek için gerekli olan günlük ya da saatlik enflasyonu ölçmek, özellikle sıklık verileri kullanan araștırmacılar için bir dönüm noktası, finansal ve reel piyasa yatırımcıları için de getiri hesabında bir yardımcı faktör olarak görülmektedir.

Doğal olarak gelișmekte olan ülkelerde yașanan ekonomik zorlukların kaynağını olușturan enflasyonun ekonomik hayatı her dakika etkilemesi ve fiyat artıșlarının alım gücünü günlük bazda etkileyerek hem hane halkı tüketimini hem de yatırım harcamalarını etkilemektedir. Bu kapsamda, bu sıklıktaki veri milli gelirin içeriği olușturan tüketim ve diğer harcamaların daha rasyonel yapılmasının önünü açar ve piyasa etkinliğinin artmasına yardımcı olur.

Bu amaçlar doğrultusunda, çalıșmamız sonucunda elde edilen Online fiyat endeksi online veri ve resmi metodolojinin kombinasyonundan olușmuștur. Türkiye'yi temsil etmesi açısından her gelir gurubundan ve tüm nüfusu temel alan bir kapsam olușturulmaya çalıșılmıștır. Elde edilen günlük enflasyon verisinde stabil ve așırı volatil olduğu dönemler söz konusu olup, bu durumun șirketlerin aylık ya da dönemsel fiyatlama politikalarının belirlenmesinde etkili olacağını düșünmekteyiz. 


\section{Kaynakça}

Cavallo, Alberto; Online and official price indexes: Measuring Argentina's inflation, Journal of Monetary Economics; October, 9, 2012

Central Bank of Turkey; Expectation Survey; October, 2020

Barrionuevo, A.; 2011 . Inflation, an old scourge, plagues Argentina again; New York Times; February 5, 2011.

United Nations Department of Economic and Social Affairs; Classification of Individual Consumption According to Purpose (COICOP) 2018; New York, 2018

Cavallo, Alberto; Cruces, Guillermo; Perez-Truglia, Ricardo; Learning From PotentiallyBiased Statistics: Household Inflation Perception and Exceptations in Argentina; National Bureau of Economic Research; March, 2016

Hiris, Lorene S.; A Daily Inflation Index; The American Economist, Vol. 36, No. 2, pp. 19-29; Fall, 1992

Wanabe, Kota; Wanabe, Tsutomu; Estimating Daily Inflation Using Scanner Data: A Progress Report; February, 16, 2014 
